\title{
FITOREMEDIASI TANAH TERCEMAR LOGAM TIMBAL (Pb) MENGGUNAKAN TANAMAN LIDAH MERTUA (Sansevieria trifasciata) DAN JENGGER AYAM (Celosia plumosa)
}

\author{
Rhenny Ratnawati ${ }^{1}$, Risna Dwi Fatmasari ${ }^{2}$ \\ 1,2 Program Studi Teknik Lingkungan, Fakultas Teknik Sipil dan Perencanaan, Universitas PGRI Adi Buana \\ Surabaya, Indonesia \\ 1ratnawati@unipasby.ac.id
}

\begin{abstract}
Soil is a very influential medium of human survival. One of the parameters affecting soil quality is heavy metal concentration in soil, especially heavy metal of lead $(\mathrm{Pb})$. High concentrations of $\mathrm{Pb}$ in the soil can treated with phytoremediation techniques. The aims of this research are: 1 . To investigate the reduction of heavy metal $\mathrm{Pb}$ in the soil by phytoremediation, 2. To investigate the effectiveness of plants to absorb heavy metal $\mathrm{Pb}$ in the soil, and 3 . To investigate the distribution of $\mathrm{Pb}$ concentration in the plant parts. The study variables used in this research are species variation of plants Sansevieria trifasciata and Celosia pulmosa. Phytoremediation test of $\mathrm{Pb}$ heavy metal contaminated soil was carried out for 4 weeks with sampling time on days $0,7,14,21$, and 28. The parameters analyzed of this research is $\mathrm{Pb}$ concentrations on soil and plant parts, namely roots, stems, leaf. Physical observations of plants were also carried out to support this research. The results show that the reactor with Sansevieria trifasciata had a higher effectiveness of removal of $\mathrm{Pb}$ in $81.08 \%(112 \mathrm{mg} / \mathrm{kg})$ than Celosia pulmosa in $59.63 \%(293 \mathrm{mg} / \mathrm{kg})$. The effectiveness of the absorption of Sansevieria trifasciata was higher $70.50 \%(418 \mathrm{mg} / \mathrm{kg}$ ) than Celosia pulmosa $52.40 \%$ (311 mg/kg). The distribution of $\mathrm{Pb}$ concentrations in the plant of Sansevieria trifasciata and Celosia pulmosa is almost the same, with the most concentration being in the root part and at least scattered in the leaves of the plant.

Keywords: Celosia pulmosa, Soil, Lead, Phytoremediation, Sanseviera trifasciata.
\end{abstract}

\begin{abstract}
Abstrak
Tanah merupakan media yang sangat berpengaruh terhadap kelangsungan hidup manusia. Kualitas tanah dipengaruhi oleh konsentrasi logam berat. Konsentrasi $\mathrm{Pb}$ yang tinggi dalam tanah dapat diatasi dengan teknik fitoremediasi. Tujuan penelitian ini adalah: 1. Mengkaji reduksi logam berat $\mathrm{Pb}$ di tanah dengan fitoremediasi, 2. Mengkaji efisiensi tanaman dalam menyerap logam berat $\mathrm{Pb}$ dalam tanah, dan 3. Mengkaji persebaran konsentrasi $\mathrm{Pb}$ dalam bagian-bagian tanaman. Variasi jenis tanaman yang digunakan pada penelitian ini adalah lidah mertua (Sansevieria trifasciata) dan jengger ayam (Celosia pulmosa). Fitoremediasi tanah tercemar logam berat $\mathrm{Pb}$ dilakukan selama 4 minggu dengan waktu pengambilan sampel pada hari ke$0,7,14,21$, dan 28. Parameter yang dianalisis adalah konsentrasi logam berat $\mathrm{Pb}$ pada tanah dan bagianbagian tanaman, yaitu akar, batang, dan daun. Pengamatan fisik tanaman juga dilakukan untuk mendukung penelitian ini. Hasil penelitian menunjukkan reaktor dengan tanaman lidah mertua (Sansevieria trifasciata) mempunyai nilai efisiensi penyisihan konsentrasi $\mathrm{Pb}$ akhir di tanah sebesar 81,08\% (112 mg/kg). Reaktor dengan tanaman jengger ayam (Celosia pulmosa) nilai efisiensi penyisihannya adalah 59,63\% (293 mg/kg). Efisiensi penyerapan tanaman lidah mertua (Sansevieria trifasciata) lebih tinggi mencapai $70,50 \%$ (418 $\mathrm{mg} / \mathrm{kg}$ ) dibandingkan jengger ayam (Celosia pulmosa) 52,40\% (311 mg/kg). Persebaran konsentrasi Pb pada tanaman lidah mertua (Sansevieria trifasciata) dan jengger ayam (Celosia pulmosa) mempunyai konsentrasi tertinggi pada bagian akar dan sebaliknya nilai terendah pada bagian daun tumbuhan.

Kata Kunci: fitoremediasi, jengger ayam, lidah mertua, logam berat timbal, tanah.
\end{abstract}

\section{PENDAHULUAN}

Pencemaran tanah dan air dapat disebabkan diantaranya oleh limbah industri, p-ISSN: 2460-8815, e-ISSN: 2549-1652 limbah rumah potong ayam, limbah penambangan, residu pupuk, dan pestisida (Kholif dan Ratnawati, 2017). Limbah yang 
dihasilkan dari kegiatan industri mempunyai konsentrasi logam berat yang tinggi. Logam berat dalam tanah berimplikasi pada terangkutnya logam berat tersebut dalam jaringan tanaman, terutama bila logam berat terdapat dalam bentuk terlarut. Bila tanaman yang mengikatnya adalah tanaman pangan seperti padi maka pencemaran logam berat akan lebih berbahaya bagi manusia. Hasil tanaman padi sawah juga mengandung logam berat seperti $\mathrm{Cu}, \mathrm{Zn}, \mathrm{Pb}, \mathrm{Cd}, \mathrm{Co}, \mathrm{Cr}$, dan Ni yang tertranslokasi dalam jerami dan beras. Logam berat yang masuk ke dalam tubuh manusia dapat membahayakan tubuh dan menyebabkan toksisitas kronis sehingga dapat merusak fungsi organ hati, ginjal, dan kerapuhan tulang.

Konsentrasi logam berat dalam tanah dapat dikurangi melalui penanaman tanaman pengikat logam berat dengan proses fitoremediasi dengan tanaman hiperakumulator. Fitoremediasi adalah teknologi untuk memperbaiki lahan dengan menggunakan tanaman (Mangkoedihardjo dkk., 2008). Salah satu mekanisme pengikatan logam berat dalam tanah oleh tanaman pengikat logam dilakukan melalui penyerapan. Mangkoedihardjo dan Samudro (2010) juga menyimpulkan fitoremediasi merupakan alternatif teknologi pengolahan tanah tercemar yang ramah lingkungan, efektif, dan mempunyai biaya yang lebih rendah dibandingkan pengolahan lainnya.

Tanaman yang digunakan untuk proses fitoremediasi mempunyai bentuk yang beraneka ragam, baik yang berwujud seperti alang-alang maupun membentuk jalinan berupa rumput. Tanaman hiperakumulator merupakan tanaman yang dapat hidup pada keadaan dimana konsentrasi logam berat yang tinggi, tanaman ini juga dapat menyerap logam dalam tanah. Sehingga dengan tanaman hiperakumulator, konsentrasi logam berat dalam tanah akan berkurang.

Tanaman lidah mertua (Sansevieria trifasciata) dan jengger ayam (Celosia pulmosa) merupakan tanaman hiperakumulator yang dapat meremediasi tanah yang tercemar logam berat $\mathrm{Pb}$. Yusuf dkk. (2014) menyimpulkan bahwa tanaman lidah mertua (Sansevieria trifasciata) memiliki kemampuan menyerap konsentrasi $\mathrm{Pb}$ dalam tanam sebesar 56,63\%. Penelitian yang dilakukan Alam dan Juhriah (2016) menyebutkan bahwa tanaman jengger ayam (Celosia pulmosa) memiliki kemampuan menyerap konsentrasi $\mathrm{Pb}$ dalam tanah sebesar $74,44 \%$. Pada penelitian yang dilakukan sebelumnya, konsentrasi pencemar yang diberikan terhadap tanaman terlalu sedikit dan waktu penanaman yang singkat, sehingga perlu ditambahkan variasi konsentrasi yang lebih tinggi dan waktu yang lebih lama. Hal ini untuk mengetahui lebih jelas pengaruh pencemar pada pertumbuhan tanaman. Selain itu juga untuk mengetahui konsentrasi pencemar maksimal yang dapat diterima oleh tanaman. Tujuan penelitian ini adalah: 1. Mengetahui penurunan konsentrasi $\mathrm{Pb}$ di tanah dengan fitoremediasi, 2. Mengetahui efisiensi tanaman dalam menyerap logam berat $\mathrm{Pb}$ dalam tanah, dan 3. Mengetahui persebaran konsentrasi $\mathrm{Pb}$ dalam bagianbagian tanaman.

\section{METODE PENELITIAN Aklimatisasi}

Aklimatisasi bertujuan agar tanaman uji dapat beradaptasi dengan kondisi lingkungan dan media tanamnya sehingga dapat bertahan hidup sampai akhir penelitian (Patandungan dkk., 2016). Tanaman yang didapat kemudian dibersihkan dari kotorann yang menempel untuk selanjutnya diaklimatisasi sebelum penelitian. Aklimatisasi tanaman dilakukan dengan menumbuhkan tanaman dalam pot yang berisikan tanah tidak tercemar selama 2 minggu sebelum dilakukan pengujian sesungguhnya, kemudian setelah 2 minggu aklimatisasi dilakukan penyortiran. Pada tahap aklimatisasi diamati berupa keberhasilan tumbuh tanaman. Karakteristik tanaman yang digunakan untuk penelitian selanjutnya adalah tumbuh subur dan tidak mengalami kematian (Ratnawati dan Talarima, 2017).

\section{Range Finding Test (RFT)}

Tahap ini bertujuan untuk menentukan konsentrasi $\mathrm{Pb}$ maksimal yang dapat ditoleransi oleh tanaman (Tangahu dan Ningsih, 2016). RFT dilakukan selama 7 hari dan dilakukan pengamatan secara morfologi terhadap tanaman. Selanjutnya dilihat pada hari ke-7, apabila tanaman tetap segar pada hari ke-7, maka konsentrasi tersebut dapat digunakan sebagai konsentrasi uji. Apabila tanaman mengalami kematian atau layu pada hari ke-7, maka konsentrasi tersebut terlalu tinggi bagi tanaman sehingga harus dilakukan kembali RFT dengan variasi konsentrasi yang berbeda. 
Pada penelitian ini, menggunakan konsentrasi pencemar sebesar $0 \mathrm{mg} / \mathrm{kg}, 200$ $\mathrm{mg} / \mathrm{kg}, \quad 500 \mathrm{mg} / \mathrm{kg}$, dan $800 \mathrm{mg} / \mathrm{kg}$. Konsentrasi logam berat yang tidak menimbulkan efek bagi tanaman digunakan untuk uji fitoremediasi tanah tercemar logam berat $\mathrm{Pb}$. Pencemar logam $\mathrm{Pb}$ berasal dari pereaksi Pb-organik $\left(\mathrm{Pb}\left(\mathrm{CH}_{3} \mathrm{COO}\right)_{2}\right)$ yang berupa padatan kemudian dilarutkan dalam air dengan konsentrasi tertentu. Larutan $\mathrm{Pb}$ dengan konsentrasi tersebut dituangkan ke dalam tanah secara merata.

\section{Fitoremediasi Tanah Tercemar Logam Berat Pb}

Konsentrasi logam berat yang digunakan pelaksanaan penelitian diperoleh dari tahap RFT. Tanaman masing-masing ditanam pada media tanah sebanyak $2 \mathrm{~kg}$ dengan konsentrasi tertentu. Pengambilan sampel secara acak dilakukan untuk tanah dan tanaman. Sampel tanah diambil setiap minggu selama 4 minggu sebanyak 10 gram. Begitu juga sampel tanaman (akar, batang, dan daun) diambil tiap minggu selama 4 minggu. Keadaan fisiologis tanaman juga diamati setiap minggunya. Uji yang dilakukan adalah penetapan konsentrasi $\mathrm{Pb}$ dalam tanah dan tanaman dengan metode Atomic Absorption Spectropotometer (AAS).

\section{HASIL DAN PEMBAHASAN \\ Karakteristik Awal Konsentrasi Pb}

Karakteristik awal konsentrasi $\mathrm{Pb}$ pada tanah kontrol, tanaman lidah mertua (Sansevieria trifasciata), dan jengger ayam (Celosia pulmosa) berturut-turut sebesar 95 $\mathrm{mg} / \mathrm{kg}, 76 \mathrm{mg} / \mathrm{kg}$, dan $22 \mathrm{mg} / \mathrm{kg}$ (Tabel 1). Hal ini terjadi pada Yusuf dkk. (2014) dimana tanaman dan tanah yang belum mengalami proses fitoremediasi juga mengandung $\mathrm{Pb}$ dengan jumlah tertentu.

Tabel 1. Karakteristik Awal Konsentrasi Pb dalam Tanah

\begin{tabular}{lc}
\multicolumn{1}{c}{ Reaktor } & $\begin{array}{c}\text { Konsentrasi Pb } \\
\text { (mg/kg) }\end{array}$ \\
\hline $\begin{array}{l}\text { Tanah (kontrol) } \\
\text { Tanaman Lidah mertua }\end{array}$ & 95 \\
$\begin{array}{l}\text { (Sansevieria trifasciata) } \\
\text { Tanaman Jengger ayam } \\
\text { (Celosia pulmosa) }\end{array}$ & 76 \\
\hline
\end{tabular}

Adanya logam $\mathrm{Pb}$ dalam tanaman terjadi karena kemungkinan terjadi proses penyerapan $\mathrm{Pb}$ pada media sebelumnya. Pada dasarnya $\mathrm{Pb}$ terkandung di tanah secara alami p-ISSN: 2460-8815, e-ISSN : 2549-1652 sebagai salah satu jenis mineral mikro, sehingga pada analisis pendahuluan $\mathrm{Pb}$ juga terkandung dalam tanah yang tidak ditambah pencemar (kontrol).

\section{Hasil RFT}

Dari hasil pengamatan selama 7 hari, terlihat bahwa tanaman lidah mertua (Sansevieria trifasciata) maupun jengger ayam (Celosia pulmosa) dapat hidup dengan baik pada konsentrasi $0 \mathrm{mg} / \mathrm{kg}, 200 \mathrm{mg} / \mathrm{kg}$, dan $500 \mathrm{mg} / \mathrm{kg}$. Keadaan tetap segar serta tumbuh tunas baru terlihat pada tanaman Lidah mertua (Sansevieria trifasciata) maupun Jengger ayam (Celosia pulmosa) tersebut. Sedangkan pada konsentrasi $800 \mathrm{mg} / \mathrm{kg}$, tanaman mengalami kematian, layu, dan menguning. Dapat diketahui bahwa maksimum konsentrasi $\mathrm{Pb}$ yang masih dapat ditoleransi oleh lidah mertua (Sansevieria trifasciata) dan jengger ayam (Celosia pulmosa) yaitu $500 \mathrm{mg} / \mathrm{kg}$. Sehingga konsentrasi yang digunakan untuk penelitian utama yaitu $0 \mathrm{mg} / \mathrm{kg}, 200 \mathrm{mg} / \mathrm{kg}$, dan 500 $\mathrm{mg} / \mathrm{kg}$.

\section{Penyisihan Konsentrasi Pb dalam Tanah}

Penyisihan konsentrasi $\mathrm{Pb}$ dalam tanah pada keseluruhan reaktor mengalami penurunan sampai dengan akhir penelitian (Gambar 1 dan 2). Konsentrasi $\mathrm{Pb}$ awal konsentrasi $200 \mathrm{mg} / \mathrm{kg}$ dan $500 \mathrm{mg} / \mathrm{kg}$ berturut-turut adalah $291 \mathrm{mg} / \mathrm{kg}$ dan 592 $\mathrm{mg} / \mathrm{kg}$. Konsentrasi $\mathrm{Pb}$ akhir pada reaktor yang menggunakan tanaman lidah mertua (Sansevieria trifasciata) pada LM0, LM200, dan LM500 berturut-turut adalah $30 \mathrm{mg} / \mathrm{kg}$, $60 \mathrm{mg} / \mathrm{kg}$, dan $112 \mathrm{mg} / \mathrm{kg}$. Reaktor menggunakan tanaman jengger ayam (Celosia pulmosa) konsentrasi $\mathrm{Pb}$ akhir pada JA0, JA200, dan JM500 masing-masing adalah 59 $\mathrm{mg} / \mathrm{kg}, \quad 115 \mathrm{mg} / \mathrm{kg}$, dan $239 \mathrm{mg} / \mathrm{kg}$. Konsentrasi $\mathrm{Pb}$ di tanah pada reaktor menggunakan tanaman lidah mertua (Sansevieria trifasciata) mempunyai nilai yang lebih rendah dibandingkan dengan reaktor tanaman jengger ayam (Celosia pulmosa). 


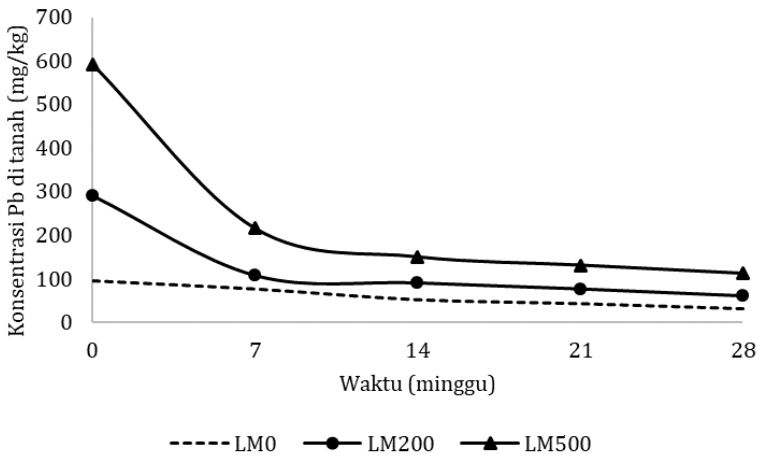

Gambar 1. Penurunan Konsentrasi Pb dalam Tanah Menggunakan Tanaman Lidah Mertua (Sansevieria trifasciata)

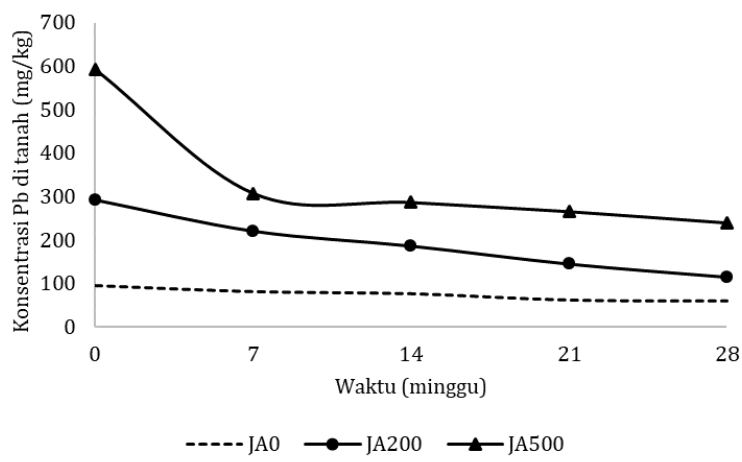

Gambar 2. Penurunan Konsentrasi Pb dalam Tanah Menggunakan Jengger Ayam (Celosia pulmosa)

Penurunan konsentrasi ini dapat diakibatkan oleh perpindahan logam secara difusi dan osmosis dimana massa zat pada media dengan konsentrasi yang tinggi (tanah) akan berpindah ke media dengan konsentrasi yang rendah (tanaman). Penurunan konsentrasi logam dalam tanah dengan menggunakan lidah mertua (Sansevieria trifasciata) maupun jengger ayam (Celosia pulmosa) paling besar terjadi pada minggu pertama, hal ini disebabkan oleh proses perpindahan logam dan kemampuan tanaman dalam menyerap logam berat. Logam berat yang terkandung dalam tanah mempunyai nilai yang tinggi pada minggu pertama, sedangkan mempunyai nilai yang rendah pada tanaman sehingga terdapat selisih yang cukup signifikan antara kedua media tersebut. Hal ini mengakibatkan logam berat yang ada dalam tanah dapat diserap dengan maksimal oleh tanaman. Sedangkan pada minggu kedua sampai keempat penyerapannya lebih sedikit karena konsentrasi logam dalam tanaman, atau dapat dikatakan toksisitas dari tanaman semakin meningkat (Yusuf dkk., 2014).

Dapat diamati pada Gambar 3 dan 4 bahwa nilai efektifitas penyisihan semakin meningkat setiap minggunya. Pada reaktor
LM0, LM200, dan LM500 mempunyai nilai efektifitas penurunan konsentrasi $\mathrm{Pb}$ berturut-turut adalah 68,42\%; 79,38\%; dan 81,08\%. Reaktor JM0, JM200, dan JM500 masing-masing adalah 37,89\%; 60,48\%; dan $59,63 \%$. Penyisihan konsentrasi $\mathrm{Pb}$ pada semua reaktor terjadi karena proses fitoremediasi yaitu adanya proses rhizodegradasi. Logam berat $\mathrm{Pb}$ diuraikan oleh mikroorganisme dalam tanah yang diperkuat dengan zat-zat keluaran akar (eksudat), yaitu gula, alkohol, asam. Eksudat ini merupakan makanan mikroorganisme yang menguraikan polutan maupun biota tanah lainnya. Faktor ini menjadikan tanaman berperan sebagai metal excluder (Ghosh dan Singh, 2005). Juhriah dkk., (2017) menyimpulkan bahwa tanaman jengger ayam (Celosia pulmosa) dengan spesies Celosia plumose berpotensi sebagai tanaman agen fitoremediasi dalam tanah. Jaswiah dkk. (2015) dalam penelitiannya menggunakan tanaman lidah mertua (Sansevieria trifasciata) untuk merediasi tanah yang kontaminasi logam berat $\mathrm{Cd}$ dan $\mathrm{Ni}$.

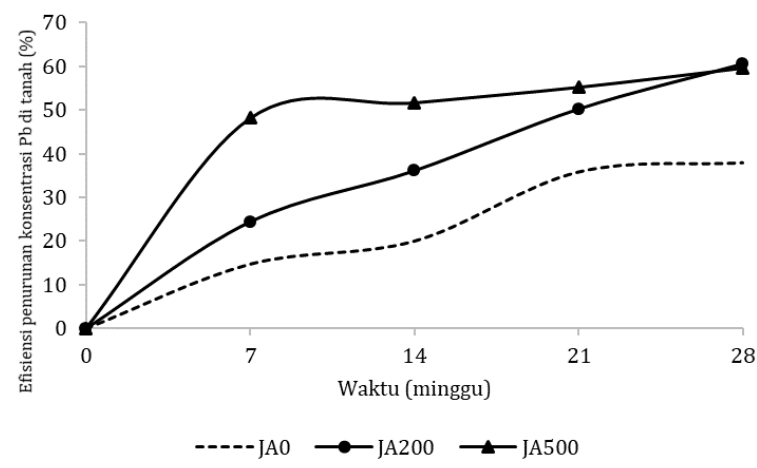

Gambar 3. Efektifitas Penurunan Konsentrasi Pb dalam Tanah Menggunakan Tanaman Lidah Mertua (Sansevieria trifasciata)

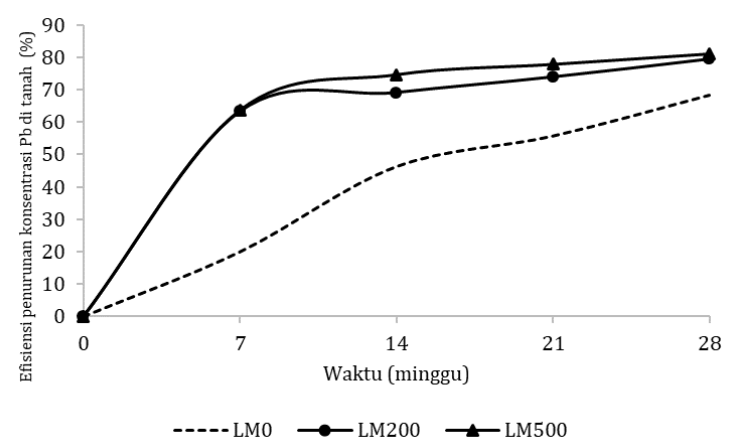

Gambar 4. Efektifitas Penurunan Konsentrasi Pb dalam Tanah Menggunakan Jengger Ayam (Celosia pulmosa)

Penyerapan Konsentrasi Pb oleh Tanaman Penyerapan konsentrasi $\mathrm{Pb}$ oleh tanaman bertujuan mengetahui jumlah konsentrasi $\mathrm{Pb}$ 
yang diserap oleh tanaman lidah mertua (Sansevieria trifasciata) dan jengger ayam (Celosia pulmosa). Konsentrasi $\mathrm{Pb}$ dalam tanaman lidah mertua (Sansevieria trifasciata) yang awalnya sama kemudian setelah dilakukan proses fitoremediasi, terdapat perubahan yang signifikan dari masingmasing reaktor (Gambar 5). Konsentrasi $\mathrm{Pb}$ dalam tanaman di akhir penelitian pada LM0, LM200, dan LM500 masing-masing adalah 127 $\mathrm{mg} / \mathrm{kg}, 201 \mathrm{mg} / \mathrm{kg}$, dan $418 \mathrm{mg} / \mathrm{kg}$. Hal tersebut juga terjadi pada reaktor tanaman jengger ayam (Celosia pulmosa) dimana terjadi peningkatan konsentrasi $\mathrm{Pb}$ dari hari ke-0 sampai 28 (Gambar 6). Di akhir penelitian, konsentrasi $\mathrm{Pb}$ dalam tanaman jengger ayam (Celosia pulmosa) pada JA0, JA200, dan JA500 berturut-turut adalah $43 \mathrm{mg} / \mathrm{kg}, 141 \mathrm{mg} / \mathrm{kg}$, dan $311 \mathrm{mg} / \mathrm{kg}$.

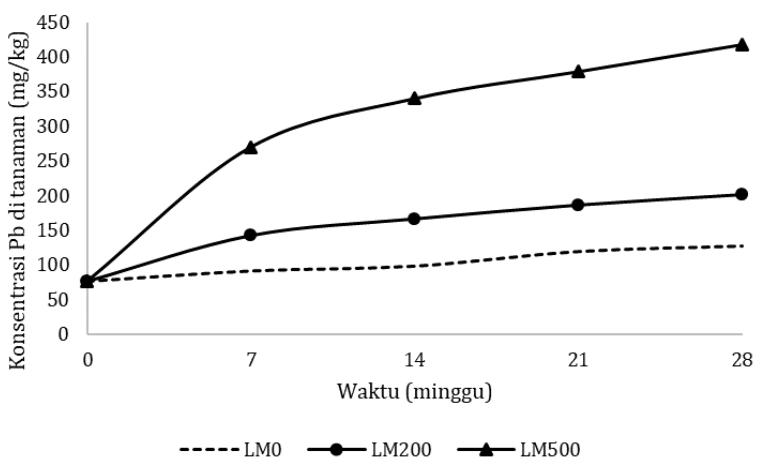

Gambar 5. Penyerapan Konsentrasi Pb pada Tanaman Lidah Mertua (Sansevieria trifasciata)

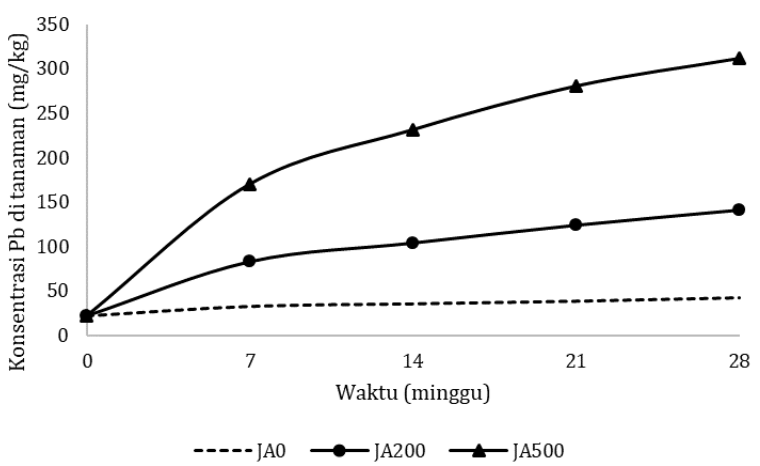

Gambar 6. Penyerapan Konsentrasi Pb pada Tanaman Jengger Ayam (Celosia pulmosa)

Kenaikan konsentrasi logam $\mathrm{Pb}$ dalam tanaman yang diperoleh kemudian digunakan untuk menghitung nilai efektifitas penyerapan $\mathrm{Pb}$ dalam tanaman. Nilai efektifitas penyerapan $\mathrm{Pb}$ pada tanaman bertujuan mengetahui seberapa efektif tanaman dalam menyerap $\mathrm{Pb}$, yang merupakan pencemar yang ditambahkan dengan konsentrasi yang berbeda-beda pada masing-masing reaktor.
Nilai Gambar 7 dan 8 menunjukkan nilai efektifitas pada masing-masing reaktor.

Tanaman lidah mertua (Sansevieria trifasciata) dapat menyerap konsentrasi $\mathrm{Pb}$ dalam tanah sampai dengan $70,50 \% ; 69,10 \%$, dan $53,70 \%$ pada reaktor masing-masing adalah LM500, LM200, dan LM0 (Gambar 7). Pada reaktor menggunakan tanaman jengger ayam (Celosia pulmosa) pada JA500, JA200, dan JA0 mempunyai efisiensi penyerapan konsentrasi $\mathrm{Pb}$ dalam tanaman adalah $52,40 \% ; 48,50 \%$, dan 22,10\% (Gambar 8).

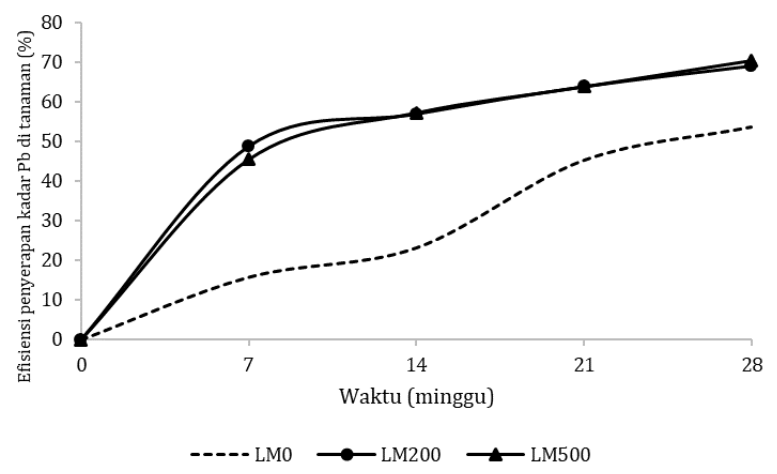

Gambar 7. Efektifitas Penyerapan Konsentrasi Pb pada Tanaman Lidah Mertua (Sansevieria trifasciata)

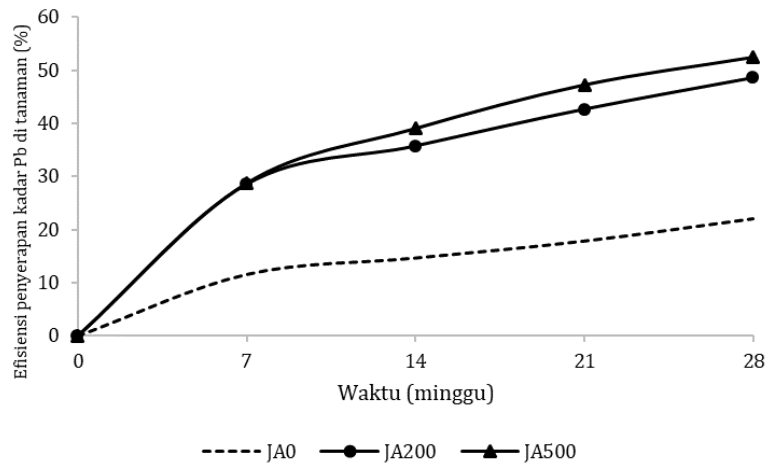

Gambar 8. Efektifitas Penyerapan Konsentrasi Pb pada Tanaman Jengger Ayam (Celosia pulmosa)

Efektifitas penyerapan tanaman lidah mertua (Sansevieria trifasciata) mempunyai nilai yang lebih tinggi dibandingkan dengan tanaman jengger ayam (Celosia pulmosa). Hal ini dapat terjadi karena tanaman lidah mertua (Sansevieria trifasciata) memiliki zat aktif pregnane glikosid (Purwanto, 2006). Polutan yang telah diserap kemudian dikirim ke akar, pada bagian akar, mikroba melakukan proses detoksifikasi. Proses detoksifikasi ini menggunakan zat aktif pregnane glikosid. Melalui proses ini, mikroba menghasilkan suatu zat yang diperlukan oleh tanaman seperti asam amino, gula, dan asam organik. 
Disamping itu, pengamatan secara fisik selama penelitian juga menunjukkan bahwa tanaman lidah mertua (Sansevieria trifasciata) tetap dapat bertahan hidup sampai dengan akhir penelitian. Penyerapan logam $\mathrm{Pb}$ oleh tanaman dapat memberikan pengaruh pada pertumbuhan dari tanaman itu sendiri. Purwanto (2006) menyimpulkan bahwa tanaman lidah mertua (Sansevieria trifasciata) memiliki keunggulan yang jarang ditemukan pada tanaman lain, diantaranya sangat resisten terhadap polutan. Pengaruh logam berat terhadap tanaman bisa dilihat dari karakteristik fisik tanaman berupa tinggi tanaman, lebar daun dan berat tanaman.

Pada penelitian tanaman lidah mertua (Sansevieria trifasciata) dengan berbagai konsentrasi selama waktu pemaparan tidak menunjukkan perubahan fisik tanaman. Berbeda dengan tanaman jengger ayam (Celosia pulmosa), yang pada konsentrasi pencemar $500 \mathrm{mg} / \mathrm{kg}$, pada minggu kedua layu dan pada minggu ketiga tanaman mati. Hal ini menunjukkan bahwa tanaman lidah mertua (Sansevieria trifasciata) lebih resisten terhadap polutan dibandingkan dengan tanaman Jengger ayam (Celosia pulmosa).

Konsentrasi logam berat dalam tanaman dapat mengalami penurunan karena proses penguraian secara alami. Mangkoedihardjo dan Samudro (2010) menyebutkan bahwa proses penguraian yang berlangsung dalam tumbuhan terdapat tiga tahap fitoproses yaitu: 1. Fitoekstraksi adalah proses penyerapan kontaminan dari medium tumbuhnya. Kontaminan terserap tumbuhan selanjutnya terdistribusi ke dalam berbagai organ tumbuhan (translokasi), 2. Fitodegradasi adalah penguraian kontaminan yang terserap melalui proses metabolik dalam tumbuhan, dan 3. Fitovolatilisasi adalah proses pelepasan kontaminan ke udara setelah terserap tumbuhan.

\section{Persebaran konsentrasi logam Pb di bagian-bagian tanaman}

Konsentrasi logam $\mathrm{Pb}$ pada bagian-bagian tanaman mempunyai nilai yang berbeda (Gambar 9 dan 10). Konsentrasi $\mathrm{Pb}$ pada daun tanaman lidah mertua (Sansevieria trifasciata) tidak sama dengan pada daun tanaman jengger ayam (Celosia pulmosa), begitu pula pada bagian tanaman lainnya seperti akar dan batang. Pada akhir penelitian dilakukan pengujian konsentrasi $\mathrm{Pb}$ pada bagian-bagian tubuh tanaman.
Pada Gambar 9 dan 10 menunjukkan konsentrasi $\mathrm{Pb}$ tertinggi terdapat pada bagian akar tanaman. Hal ini karena proses masuknya konsentrasi $\mathrm{Pb}$ dalam jaringan. Jaringan akar mempunyai interaksi langsung dengan tanah (media) yang terkontaminasi pencemar berupa $\mathrm{Pb}$, sehingga konsentrasi $\mathrm{Pb} \mathrm{di}$ jaringan akar cenderung lebih tinggi daripada batang maupun daun. Unsur hara dapat kontak dengan permukaan akar melalui tiga cara, yakni secara difusi dalam larutan tanah, secara pasif terbawa aliran air tanah dan karena akar kontak dengan hara tersebut di dalam matrik tanah (Yusuf dkk., 2014). Konsentrasi $\mathrm{Pb}$ pada bagian tanaman lidah mertua (Sansevieria trifasciata) lebih tinggi daripada bagian tanaman jengger ayam (Celosia pulmosa).

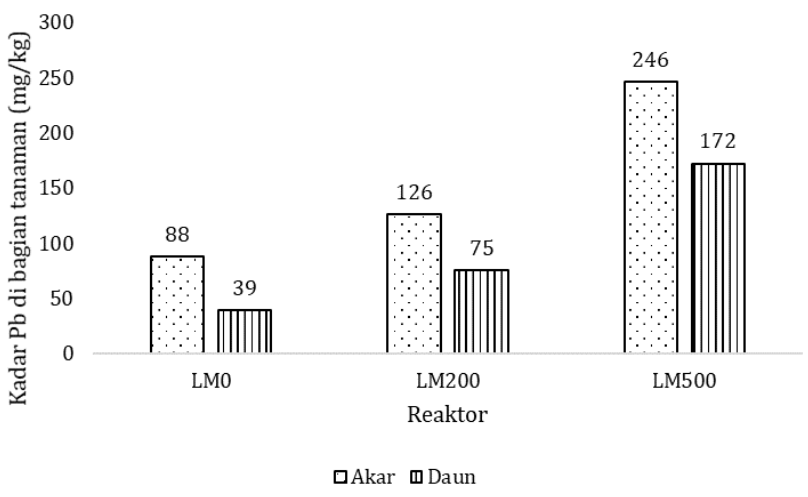

Gambar 9. Persebaran Konsentrasi Pb pada Bagian Tanaman Lidah Mertua (Sansevieria trifasciata)

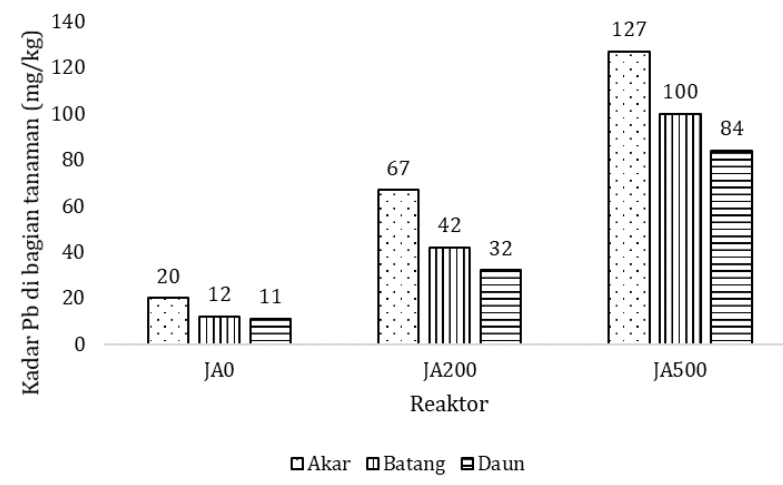

Gambar 10. Persebaran Konsentrasi Pb pada Bagian Tanaman Jengger Ayam (Celosia pulmosa)

\section{Konsentrasi $\mathrm{Pb}$ yang hilang}

Konsentrasi $\mathrm{Pb}$ yang hilang dapat dihitung dengan selisih konsentrasi pencemar pada tanah dengan tanaman. Pada reaktor LM0, LM200, dan LM500 konsentrasi Pb yang hilang berturut-turut adalah $14 \mathrm{ppm}, 30 \mathrm{ppm}$, dan 63 ppm (Tabel 2). Sementara pada reaktor JA0, JA200, dan JA500 konsentrasi $\mathrm{Pb}$ 
yang hilang masing-masing adalah 15, ppm, 35 ppm, dan 43 ppm.

Tabel 2. Konsentrasi Pb yang Hilang

\begin{tabular}{|c|c|c|c|c|c|}
\hline \multirow[t]{2}{*}{ Reaktor } & \multicolumn{2}{|c|}{$\begin{array}{l}\text { Konsentrasi } \mathrm{Pb} \\
\text { dalam Tanah } \\
\text { (mg/kg) }\end{array}$} & \multicolumn{2}{|c|}{$\begin{array}{c}\text { Konsentrasi Pb } \\
\text { dalam } \\
\text { Tanaman } \\
(\mathrm{mg} / \mathrm{kg}) \\
\end{array}$} & \multirow[t]{2}{*}{$\begin{array}{c}\text { Konsentrasi } \\
\text { Pb yang } \\
\text { hilang } \\
\text { (mg/kg) }\end{array}$} \\
\hline & Awal & Akhir & Awal & Akhir & \\
\hline LM0 & 95 & 30 & & 127 & 14 \\
\hline LM200 & 291 & 60 & 76 & 201 & 30 \\
\hline LM500 & 593 & 112 & & 418 & 63 \\
\hline JA0 & 95 & 59 & & 43 & 15 \\
\hline JA200 & 291 & 115 & 22 & 141 & 35 \\
\hline JA500 & 593 & 239 & & 311 & 43 \\
\hline
\end{tabular}

Konsentrasi $\mathrm{Pb}$ yang hilang ini disebabkan oleh proses penguraian logam berat oleh tanaman (proses fitoekstraksi, fitodegradasi, dan fitovolatilisasi). Selain itu, juga dapat disebabkan karena penyiraman selama penelitian berlangsung, dimana dimungkingkan terdapat perpindahan logam berat pada tanah dan tanaman. Logam berat yang tersebar di bagian akar tanah akan turun dan mengumpul di dasar reaktor. Sehingga pada saat pengambilan sampel, mungkin saja tanah yang terambil tidak mengandung terlalu banyak logam (Yusuf dkk., 2014).

\section{KESIMPULAN}

Kesimpulan yang dapat diperoleh dari penelitian ini adalah adalah konsentrasi $\mathrm{Pb}$ akhir dalam tanah dan nilai efisiensi penyisihan pada reaktor lidah mertua (Sansevieria trifasciata) kontrol, $200 \mathrm{mg} / \mathrm{kg}$, $500 \mathrm{mg} / \mathrm{kg}$ secara berturut-turut adalah 30 $\mathrm{mg} / \mathrm{kg}(68,42 \%) ; 60 \mathrm{mg} / \mathrm{kg}$ (79,38\%); dan $112 \mathrm{mg} / \mathrm{kg}(81,08 \%)$. Sementara pada reaktor jengger ayam (Celosia pulmosa) konsentrasi $\mathrm{Pb}$ akhir secara berturut-turut adalah 59 $\mathrm{mg} / \mathrm{kg}(37,89 \%) ; 115 \mathrm{mg} / \mathrm{kg}(60,48 \%) ;$ dan $239 \mathrm{mg} / \mathrm{kg}(59,63 \%)$.

Efisiensi penyerapan konsentrasi $\mathrm{Pb}$ pada tanaman lidah mertua (Sansevieria trifasciata) kontrol, $200 \mathrm{mg} / \mathrm{kg}$, dan $500 \mathrm{mg} / \mathrm{kg}$ secara berturut-turut adalah 53,70\% (127 mg/kg); 69,10\% (201 mg/kg); dan 70,50\% (418 $\mathrm{mg} / \mathrm{kg}$ ). Sementara pada tanaman jengger ayam (Celosia pulmosa) kontrol, $200 \mathrm{mg} / \mathrm{kg}$, dan $500 \mathrm{mg} / \mathrm{kg}$ berturut-turut adalah 22,10\% (43 mg/kg); 48,50\% (141 mg/kg); dan $52,40 \%$ (311 mg/kg). Tanaman lidah mertua (Sansevieria trifasciata) dapat menyerap $\mathrm{Pb}$ lebih tinggi daripada tanaman jengger ayam (Celosia pulmosa).
Penyebaran konsentrasi $\mathrm{Pb}$ akhir pada reaktor lidah mertua (Sansevieria trifasciata) pada konsentrasi $500 \mathrm{mg} / \mathrm{kg}$ tertinggi dalam akar dan daun dengan nilai $246 \mathrm{mg} / \mathrm{kg}$ dan $172 \mathrm{mg} / \mathrm{kg}$. Sementara pada reaktor jengger ayam (Celosia pulmosa) pada konsentrasi 500 $\mathrm{mg} / \mathrm{kg}$ tertinggi dalam akar, batang, dan daun dengan nilai $127 \mathrm{mg} / \mathrm{kg}, 100 \mathrm{mg} / \mathrm{kg}$, dan 84 $\mathrm{mg} / \mathrm{kg}$. Konsentrasi $\mathrm{Pb}$ di akar tanaman lidah mertua (Sansevieria trifasciata) maupun jengger ayam (Celosia pulmosa) merupakan yang tertinggi dibandingkan konsentrasi di batang dan daun.

\section{DAFTAR PUSTAKA}

Ghiovani D. dkk. (2017). Fitoremediasi Air yang Tercemar Limbah Laundry dengan Menggunakan Kayu Apu (Pistia stratiotes). Jurnal Teknik 6 (2): 232-236.

Ghosh M, Singh SP. (2005). Comparative Uptake and Phytoextraction Study of Soil Induced Chromium by Accumulator and High Biomass Weed Species. Applied Ecology and Evironmental Research 3(2): 67-79.

Juhriah dan M. Alam. (2016). Fitoremediasi Logam Berat Merkuri (Hg) pada Tanah Dengan Tanaman Celosia plumose (Voss) Burv. Jurnal Biologi Makassar, 1 (1): 1-8.

Juhriah, Sri Suhadiyah, dan Reski Mandasari. (2017). Respon Pertumbuhan Tanaman Jengger Ayam Merah Celosia plumose (Voss) Burv. pada Tanah Tercemar Logam Berat Kadmium (Cd). Jurnal Alam dan Lingkungan 8: 29-35.

Kholif, M.A., dan Ratnawati, R. (2017), Pengaruh Beban Hidrolik Media dalam Menurunkan Senyawa Ammonia pada Limbah Cair Rumah Potong Ayam (RPA). Jurnal Waktu, 15 (1): 1-9.

Mangkoedihardjo, S., Ratnawati, R. dan Alfianti, N. (2008), Phytoremediation of Hexavalent Chromium Polluted Soil Using Pterocarpus indicus and Jatropha curcas L. World Applied Sciences Journal, 4: 338-342.

Mangkoedihardjo, S dan Ganjar Samudro. 2010. Fitoteknologi Terapan. Yogyakarta: Graha Ilmu.

Patandungan A., Syamsidar HS., dan Aisyah. (2016). Fitoremediasi Tanaman Akar Wangi (Vetiver zizanioides) terhadap Tanah Tercemar Logam Kadmium (Cd) pada Lahan TPA Tamangapa Antang Makassar. Al-Kimia 4(2): 8-21.

Pierzynski, G.M. dan A.P. Schwab. (1993). Bioavailability of Zinc, Cadmium, and Lead 
in A Metal-Contaminated Alluvial Soil. J. Environ. Qual. 22: 247-254.

Purwanto, A. W. (2006). Sansevieria: Flora Cantik Penyerap Racun. Yogyakarta: Kanisius.

Yusuf, M., Achmad Z., dan Ardy A. (2014). Fitoremediasi Tanah Tercemar Logam Berat $\mathrm{Pb}$ dan $\mathrm{Cd}$ Dengan Menggunakan Tanaman Lidah Mertua (Sansevieria trifasciata).

Jaswiah, Syamsidar H., Syariffudin, dan Iin Novianti. (2016). Fitoremediasi Logam Cadmium Pada Asap Rokok Menggunakan Tanaman Lidah Mertua (Sansevieria trifasciata) Jenis Sansevieria hyancithoides dan Sansevieria trifasciata. Chimica et Natura 4 (2): 88 -92.

Ratnawati, R., dan Talarima, A. (2017), Subsurface (SSF) Constructed Wetland untuk Pengolahan Air Limbah Laundry . Jurnal Waktu, 15 (2): 1-6.

Tangahu, VT., dan Ningsih, DA., (2016), Uji Penurunan Konsentrasi COD, BOD pada Limbah Cair Pewarnaan Batik menggunakan Scirpus grossus dan Iris pseudacorus dengan Sistem Pemaparan Intermittent. 